Journal of Patient-Centered

$1-27-2020$

\title{
Lavender Aromatherapy: Ready for Prime-Time Office Use?
}

Dennis J. Baumgardner

Follow this and additional works at: https://aah.org/jpcrr

Part of the Alternative and Complementary Medicine Commons, Family Medicine Commons, Integrative Medicine Commons, Natural Products Chemistry and Pharmacognosy Commons, Neurology Commons, Neurosciences Commons, Plants Commons, Primary Care Commons, Surgical Procedures, Operative Commons, and the Therapeutics Commons

\section{Recommended Citation}

Baumgardner DJ. Lavender aromatherapy: ready for prime-time office use? J Patient Cent Res Rev. 2020;7:5-7. doi: 10.17294/2330-0698.1741

Published quarterly by Midwest-based health system Advocate Aurora Health and indexed in PubMed Central, the Journal of Patient-Centered Research and Reviews (JPCRR) is an open access, peer-reviewed medical journal focused on disseminating scholarly works devoted to improving patient-centered care practices, health outcomes, and the patient experience. 


\title{
Lavender Aromatherapy: Ready for Prime-Time Office Use?
}

\author{
Dennis J. Baumgardner, MD | Editor-in-Chief \\ Department of Family Medicine, Aurora UW Medical Group, Aurora Health Care, Milwaukee, WI
}

$\mathrm{I}$

$\mathrm{n}$ this issue of the Journal of Patient-Centered Research and Reviews, a novel article by Cathey and colleagues explores the use of lavender aromatherapy for the reduction of pain and anxiety in patients undergoing awake craniotomy. ${ }^{1}$ In this feasibility study, 31 patients were administered lavender aromatherapy via nasal inhaler preoperatively, during induction, and every 30 minutes during an awake craniotomy procedure. There were nonsignificant improvements in visual analog scale scores for anxiety after each inhalation of lavender, while pain scores were virtually unchanged after inhalation. After the surgery was completed, most patients reported being either satisfied or very satisfied with their pain management during craniotomy. ${ }^{1}$

While complex neurosurgery is not a treatment this family physician confronts on a regular basis, the study aims certainly grabbed my attention. What might be the connection to the practice of a generalist clinician such as myself?

\section{The Relaxing Power of Fragrance}

Aromatherapies, also known as essential oils, have been used as healing modalities for centuries and have physiologic bases for their actions. ${ }^{2}$ The fragrances used are composed of numerous volatile small molecules (generally terpenes and aromatic compounds), with each fragrance having a few characteristic predominant molecules. ${ }^{2}$

Examining Lavandula angustifolia (the predominant lavender species utilized for relaxation) specifically,

Correspondence: Dennis J. Baumgardner, MD, Aurora Sinai Medical Center, 1020 N. 12th Street, \#4180, Milwaukee, WI 53233 (dennis.baumgardner@aurora.org) the primary components

are geraniol, linalool, linalyl acetate, and $\beta$-caryophyllene, and these compounds attach to epithelial receptor cell cilia in the nose. ${ }^{2}$ Interactions with olfactoryreceptor proteins occur, and sensory neurons transmit electrical signals to brain

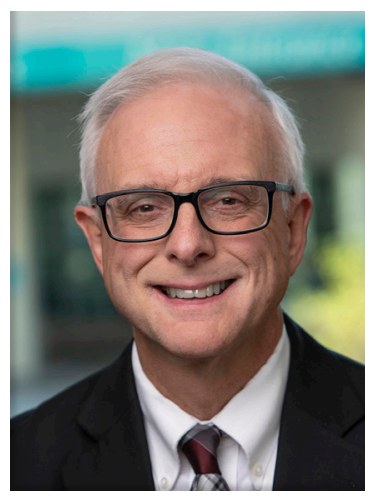
areas involved in emotions and memory. Lavender oil inhalation has been shown to affect brain wave activity, as measured by electroencephalogram (EEG) recordings. ${ }^{2}$ Effects suggested by these EEG studies include relaxing effects of increased theta activities and potentially beneficial differential effects on brain waves by region of the brain.

Other studies of physiologic changes from lavender aromatherapy have been mixed. In rats, lavender oil scents decreased blood pressure, body temperature, lipolysis, and adrenaline and increased appetite. ${ }^{3}$ Lavender aromatherapy has been shown to reduce serum cortisol and to increase coronary blood flow velocity reserve in healthy male volunteers. ${ }^{4}$ In a carefully controlled experiment in 56 healthy people, no significant physiologic changes or psychological or analgesic benefit was seen from lavender oil inhalation; however, subgroup analysis was limited by sample size. ${ }^{5}$ A controlled study of 96 healthy young women randomly assigned to lavender aromatherapy, placebo aroma, or no therapy showed no difference in galvanic skin response during relaxation between groups. ${ }^{6}$ The subset of women given lavender aromatherapy who were told (primed) to expect the therapy to "aid in relaxation and relieve anxiety" $(\mathrm{n}=11)$ experienced, paradoxically, decreased relaxation. ${ }^{6}$ 


\section{Pre-, Peri- and Postoperative Use}

Lavender aromatherapy has been used adjunctively for pain and anxiety relief in the perioperative period for several years. ${ }^{7}$ In a prospective randomized controlled trial of 54 patients administered lavender oil or placebo oil applied to the oxygen face mask immediately after arrival in the postanesthesia care unit following laparoscopic adjustable gastric banding, significant reductions in need for postoperative analgesics, including opioids, was observed in those receiving lavender. ${ }^{8}$ Similarly, in 200 post-cesarean section patients, visual analog scale pain scores were significantly improved in the lavender therapy (again, through oxygen mask) group, compared to the placebo group. ${ }^{9}$ In a smaller study, lavender aromatherapy was used in children after tonsillectomy. ${ }^{10}$ Reductions in the number of daily acetaminophen doses were seen in the aromatherapy group, but there were no statistically significant differences, compared to placebo, in pain scores or in frequency of nighttime awakening. ${ }^{10} \mathrm{~A}$ randomized study of 50 patients undergoing breast biopsy provided postoperative lavender aromatherapy through an oxygen face mask to half of the patients, while the other half received the oxygen mask without aromatherapy. ${ }^{11}$ No significant differences between groups were seen for narcotic requirements, discharge from the recovery room, or pain scores. Patients receiving aromatherapy reported higher satisfaction with pain control. ${ }^{11}$

Lavender aromatherapy also has been used preoperatively to reduce anxiety in patients preparing to undergo ambulatory otolaryngology surgery. ${ }^{12}$ Improvement in visual analog scale anxiety scores were better in the lavender group, compared to controls. However, experimental and control subjects were patients of different physicians rather than being randomized. ${ }^{12}$ In a randomized placebo-controlled study, lavender aromatherapy was shown to decrease pain and anxiety and improve patient satisfaction during peripheral vein cannulation prior to surgery. ${ }^{13}$

\section{Potential in Other Clinical Encounters}

In other venues, lavender aromatherapy, administered via a bedside jar in an intermediate care unit of a teaching hospital, resulted in significantly lower nocturnal blood pressure and a nonsignificantly higher overall sleep score in the 25 patients receiving the intervention, compared to the same number of control subjects. ${ }^{14}$ Two studies of lavender aromatherapy were undertaken in hemodialysis patients. One study found improvement in pain scores for those using inhaled lavender essence, versus control patients, following needle insertion into a fistula. ${ }^{15}$ Another documented statistically significant improvements in an anxiety inventory and a fatigue severity scale when using lavender aromatherapy, compared to a control group. ${ }^{16}$

Finally, lavender aromatherapy has been used during minor ambulatory office procedures. In a randomized placebo-controlled trial, the mean reduction in anxiety scores measured before and after a minor gynecologic procedure was greater among those who inhaled lavender from cotton, compared to a diluted milk placebo. ${ }^{17}$ In an often-quoted study by Lehrner et al, lavender aromatherapy infusion into the waiting room was associated with lower anxiety and better mood scores, compared to controls, of patients awaiting office dental procedures. ${ }^{18}$ In this study, patients were not told the true nature of the experiment until the study was over (ie, no expectations of therapy were provided), and patients were assigned consecutively, by groups of 48-51 patients per time period, to "no odor," then "uplifting" music, then lavender odor, and finally an orange odor group.

As a primary care clinician, I think the stage is set for the use of lavender aromatherapy during minor primary care office procedures. It could be used as sole therapy in situations where anesthesia or sedation is not routinely used or as an additional agent where topical or local anesthetics are the norm. It may be particularly useful for anxious or apprehensive patients.

Consider that the first 11 chapters of a standard primary care office procedures textbook are devoted to sedation and anesthesia. ${ }^{19}$ In that light, it seems well-designed controlled trials, like the one conducted by Lehrner et $a 1,{ }^{18}$ are called for to properly study the benefits of implementing routine lavender aromatherapy during minor primary care office procedures.

\section{Acknowledgments}

The author thanks Rebecca Schultz, MS, FNP-BC, HNB-BC, of Aurora Health Care for providing helpful suggestions. 


\section{References}

1. Cathey K, Gunyon N, Chung N, et al. A feasibility study of lavender aromatherapy in an awake craniotomy environment. J Patient Cent Res Rev. 2020;7:19-30.

2. Sowndhararajan K, Kim S. Influence of fragrances on human psychophysiological activity: with special reference to human electroencephalographic response. Sci Pharm. 2016;84:734-51. CrossRef

3. Nagai K, Niijima A, Horii Y, Shen J, Tanida M. Olfactory stimulatory with grapefruit and lavender oils change autonomic nerve activity and physiological function. Auton Neurosci. 2014;185:29-35. CrossRef

4. Shiina Y, Funabashi N, Lee K, et al. Relaxation effects of lavender aromatherapy improve coronary flow velocity reserve in healthy men evaluated by transthoracic Doppler echocardiography. Int J Cardiol. 2008;129:193-7. CrossRef

5. Kiecolt-Glaser JK, Graham JE, Malarkey WB, Porter $\mathrm{K}$, Lemeshow $\mathrm{S}$, Glaser R. Olfactory influences on mood and autonomic, endocrine, and immune function. Psychoneuroendocrinology. 2008;33:328-39. CrossRef

6. Howard S, Hughes BM. Expectancies, not aroma, explain impact of lavender aromatherapy on psychophysiological indices of relaxation in young healthy women. Brit $J$ Health Psychol. 2008;13:603-17. CrossRef

7. Stea S, Beraudi A, De Pasquale D. Essential oils for complementary treatment of surgical patients: state of the art. Evid Based Complement Alternat Med. 2014;2014:726341. CrossRef

8. Kim JT, Ren CJ, Fielding GA, et al. Treatment with lavender aromatherapy in the post-anesthesia care unit reduces opioid requirements of morbidly obese patients undergoing laparoscopic adjustable gastric banding. Obes Surg. 2007;17:920-5. CrossRef

9. Hadi N, Hanid AA. Lavender essence for post-cesarean pain. Pak J Biol Sci. 2011;14:664-7. CrossRef

10. Soltani R, Soheilipour S, Hajhashemi V, Asghari G, Bagheri M, Molavi M. Evaluation of the effect of aromatherapy with lavender essential oil on post-tonsillectomy pain in pediatric patients: a randomized controlled trial. Int $J$ Pediatr Otorhinolaryngol. 2013;77:1579-81. CrossRef
11. Kim JT, Wajda M, Cuff G, et al. Evaluation of aromatherapy in treating postoperative pain: pilot study. Pain Pract. 2006;6:273-7. CrossRef

12. Wotman M, Levinger J, Leung L, Kallush A, Mauer E, Kacker A. The efficacy of lavender aromatherapy in reducing preoperative anxiety in ambulatory surgery patients undergoing procedures in general otolaryngology. Laryngoscope Investig Otolaryngol. 2017;2:437-41. CrossRef

13. Karaman T, Karaman S, Dogru S, et al. Evaluating the efficacy of lavender aromatherapy on peripheral venous cannulation pain and anxiety: a prospective, randomized study. Complement Ther Clin Pract. 2016;23:64-8. CrossRef

14. Lytle J, Mwatha C, Davis KK. Effect of lavender aromatherapy on vital signs and perceived quality of sleep in the intermediate care unit: a pilot study. Am J Crit Care. 2014;23:24-9. CrossRef

15. Bagheri-Nesami M, Espahbodi F, Nikkhah A, Shorofi SA, Charati JY. The effects of lavender aromatherapy on pain following needle insertion into a fistula in hemodialysis patients. Complement Ther Clin Pract. 2014;20:1-4. CrossRef

16. Karadag E, Samancioglu Baglama S. The effect of aromatherapy on fatigue and anxiety in patients undergoing hemodialysis treatment: a randomized controlled study. Holist Nurs Pract. 2019;33:222-9. CrossRef

17. Shahnazi M, Nikjoo R, Yavarikia P, Mohammad-AlizadehCharandabi S. Inhaled lavender effect on anxiety and pain caused from intrauterine device insertion. J Caring Sci. 2012;1:255-61.

18. Lehrner J, Marwinski G, Lehr S, Johren P, Deecke L. Ambient odors of orange and lavender reduce anxiety and improve mood in a dental office. Physiol Behav. 2005;86:92-5. CrossRef

19. Fowler GC (ed). Pfenninger \& Fowler's Procedures for Primary Care, Fourth Edition. Philadelphia, PA: Elsevier, 2020.

(C) 2020 Aurora Health Care, Inc. 